вати всі питання щодо територіального верховенства і здійснення прав власника на землю Українського народу шляхом проведення переговорів та укладення міждержавних угод 3 питань врегулювання територіальних претензій з боку інших держав, встановлення лінії державного кордону, повернення тих чи інших земель до власності Українського народу тощо.

3 метою захисту суверенітету і цілісності державної території та непорушності права власності Українського народу на землю, Україна через свої центральні ограни державної влади може вирішувати територіальні спори шляхом звернення у встановленому порядку до міжнародних інституцій ООН та $\mathrm{CC}$, або ж відстоювати у цих організаціях свої права від претензій інших суб'єктів міжнародного права щодо незалежності, недоторканності, цілісності території, непорушності державного кордону i водночас забезпечувати право власності Українського народу на землю.

DOI https://doi.org/10.30525/978-9934-26-040-7-34

\title{
ДО ПИТАННЯ ПРО ПРАВОВІ ПРОБЛЕМИ МОНІТОРИНГУ ЯКОСТІ АТМОСФЕРНОГО ПОВІТРЯ В УКРАЇНI
}

\author{
Чурилова Т. М. \\ кандидат юридичних наук, дочент, \\ доиент кафедри міжнародного, європейського права \\ та ичивільно-правових дисциилін \\ Сумського державного університету \\ м. Суми, Украӥна \\ Стрельник В. В. \\ кандидат юридичних наук, доцент, \\ дочент кафедри приватного та сочуіального права \\ Сумського національного аграрного університету \\ м. Суми, Украӥна
}

Належна якість атмосферного повітря $\epsilon$ запорукою загального процвітання і благополуччя. Забруднене повітря негативно позначається не тільки на здоров’ї людей, а й впливає на екосистеми, клімат, 
економіку, завдає шкоди культурній спадщині, руйнуючи архітектурні шедеври, які є частиною національної ідентичності.

Забруднення атмосферного повітря залишається актуальною проблемою у сфері охорони довкілля для України.

Відносини в галузі охорони атмосферного повітря регулюються Законом України «Про охорону атмосферного повітря» [1] та іншими нормативно-правовими актами. Серед низки правових заходів, передбачених атмосферно-повітряним законодавством важливу роль відіграють заходи превентивного характеру, зокрема моніторинг якості атмосферного повітря, передбачений ст. 32 зазначеного закону.

Порядок організації та проведення моніторингу у галузі охорони атмосферного повітря встановлюється Кабінетом Міністрів України.

Слід зазначити, що у 2019 році Уряд прийняв Постанову № 827 від 14 серпня 2019 року «Деякі питання здійснення державного моніторингу в галузі охорони атмосферного повітря» [2], яка ознаменувала початок реформ у сфері моніторингу та управління якістю повітря, та замінила Постанову «Про затвердження Порядку організації та проведення моніторингу в галузі охорони атмосферного повітря» № 343 від 9 березня 1999 року [3].

Відповідно до глави 6, статті 361 Угоди про асоціацію між Україною та Європейським Союзом, Україна взяла на себе зобов'язання щодо співпраці у сфері охорони атмосферного повітря, а отже адаптувати національне законодавство до законодавства ЄC в частині встановлення стандартів якості атмосферного повітря щодо вмісту найбільш шкідливих забруднювачів атмосферного повітря та управління якістю атмосферного повітря [4]. Мова йде про положення двох європейських директив: 2008/50/СС про якість атмосферного повітря та чистіше повітря для Свропи [5], якою визначені рамкові вимоги щодо контролю та оцінки якості атмосферного повітря, а також Директиву 2004/107/СС про миш'як, кадмій, ртуть, нікель і поліциклічні ароматичні вуглеводні у атмосферному повітрі [6].

Завдання надзвичайно складне для України - замінити радянську систему контролю забруднення атмосферного повітря, європейською системою моніторингу із відповідним обладнанням, яка $є$ надійним інструментом розробки та реалізації природоохоронної політики.

Так, відповідно до Постанови Кабінету Міністрів України «Про затвердження Порядку організації та проведення моніторингу в галузі охорони атмосферного повітря» № 343 від 09.03.1999 р. для спостереження за забрудненням атмосфери використовувались три категорії постів: стаціонарні, маршрутні (відбір проб на території за допомогою пересувного обладнання), пересувні (під димовими i 
газовими факелами). Кількість постів залежить від розміру міста i особливостей структури промисловості.

Спостереження проводились за повною (безперервно або дискретно через рівні проміжки часу, о 1, 7, 13 і 19 годині за місцевим часом), неповною (разові концентрації о 7, 13 і 19 годині), скороченою (о 7 i 13 годині), добовою (кожні три години) програмами. Такий порядок має значні вади, адже унеможливлюе фіксацію максимальних значень у випадку, якщо вони спостерігаються у інший період доби, крім того впливає на точність усереднення.

На стаціонарних постах визначають пил, сірчистий газ, оксид вуглецю, діоксид азоту та вміст специфічних для даного населеного пункту речовин, які затверджуються рішенням органів місцевого самоврядування відповідно до специфіки екологічної ситуації. На маршрутних - визначають основні забруднювачі та специфічні речовини, характерні для даного населеного пункту. На пересувних специфічні для підприємства речовини. Отже, програми спостережень можуть значно відрізнятися на окремих постах.

Для визначення якості повітря фактичні концентрації забрудників порівнюють 3 гранично допустимими концентраціями (ГДК). Нормативи ГДК забруднюючих речовин в атмосферному повітрі визначено у Державних санітарних правилах охорони атмосферного повітря населених місць (від забруднення хімічними та біологічними речовинами), затверджених наказом МОЗ від 09 липня 1997 р. № 201, в якому регламентуються лише деякі види пилу (позиції 372-379 пункту «б» додатка 1). В Україні відсутні методики виокремлення із загальної маси пилу $\mathrm{TЧ}_{10} / \mathrm{TЧ}_{2,5}$ та не здійснюється контроль та моніторинг вмісту цих речовин в атмосферному повітрі [7].

Таким є основний, але не вичерпний перелік проблем здійснення моніторингу атмосферного повітря відповідно Постанови Кабінету Міністрів України № 343 від 09.03.1999 р. Крім наведених, слід зазначити відсутність координації між органами, що здійснюють моніторинг, відсутність інструментів впливу на забруднювачів.

У рамках виконання Україною зобов'язань в екологічній частині Угоди про асоціацію з СС, Уряд ухвалив новий Порядок здійснення державного моніторингу атмосферного повітря - Постанова № 827 від 14 серпня 2019 року «Деякі питання здійснення державного моніторингу в галузі охорони атмосферного повітря» (далі - Порядок) [2].

Так, передбачено здійснення моніторингу та управління якістю повітря за принципом розподілу території України на зони та агломерації. Порядком визначено зони (відповідають областям) та агло140 
мерації (територія з населенням понад 250 тис. осіб). Отже, частина населених місць не охоплюється поняттям агломерація, проте входять у перелік найбільш забруднених міст України [8].

До переліку забруднюючих речовин, моніторинг яких здійснюється обов'язково, включено тверді частки ТЧ 10 /ТЧ 2,5 та озон, які мають значний негативний вплив на здоров'я людини [2]. Але, у 2020 році Міністерство охорони здоров'я затвердило наказ № 52 від 14.01.2020 року «Про затвердження гігієнічних регламентів допустимого вмісту хімічних і біологічних речовин в атмосферному повітрі населених місць» [9], які не містять значення гранично допустимих концентрацій для ТЧ $\mathrm{Y}_{\mathbf{1 0}} / \mathrm{TЧ}_{\mathbf{2}, 5}$.

Порядком визначено відповідальний орган управління якістю повітря, а саме структурний підрозділ обласної держадміністрації 3 питань охорони навколишнього природного середовища, або виконавчий орган міської ради, що здійснюватиме координацію реалізації моніторингу, а також заходів з управління якістю повітря, зокрема підготовку та виконання планів поліпшення якості повітря, короткострокових планів дій тощо. Між тим, інструменти впливу на забруднювачів відсутні, отже ефективне виконання покладених функцій знаходиться під питанням.

Відповідно до вимог Директиви 2008/50/СС Порядком закріплені режими оцінювання для кожної зони та агломерації залежно від рівня забруднення території. Передбачено створення інформаційно-аналітичної системи про якість повітря для своєчасного інформування населення. Визначені 7 показників рівнів забруднення атмосферного повітря, перевищення яких вимагає впровадження заходів для поліпшення стану повітря або мінімізації шкідливого впливу забруднення на здоров'я населення.

Отже, маємо констатувати, що в цілому Порядок встановлює систему моніторингу атмосферного повітря відповідно до вимог європейського законодавства. Проте, потребують внесення змін пов'язані нормативно-правові акти. Крім того, залишається актуальним питання систематичного фінансування моніторингу атмосферного повітря.

\section{Література:}

1. Про охорону атмосферного повітря: Закон України від 16 жовтня 1992 р. № № 2707-XII / Верховна Рада України. URL: https://zakon.rada.gov.ua/laws/show/2707-12\#Text (дата звернення: 16.02.2021).

2. Деякі питання здійснення державного моніторингу в галузі охорони атмосферного повітря: Постанова Кабінету Міністрів України; 
Порядок, Перелік від 14.08.2019 № 827. База даних «Законодавство України». URL: https://zakon.rada.gov.ua/laws/show/827-2019$\% \mathrm{D} 0 \% \mathrm{BF}$ Техt (дата звернення: 13.02.2021).

3. Про затвердження Порядку організації та проведення моніторингу в галузі охорони атмосферного повітря: Постанова Кабінету Міністрів України; Порядок від 09.03.1999 № 343. База даних «Законодавство України». URL: https://zakon.rada.gov.ua/laws/show/34399-\%D0\%BF\#Техt (дата звернення: 13.02.2021).

4. Угода про асоціацію між Україною, 3 однієї сторони, та Європейським Союзом, європейським співтовариством 3 атомної енергії і їхніми державами-членами, з іншої сторони від 27.06.2014 p. База даних «Законодавство України». URL: http://zakon3.rada.gov.ua/ laws/show/984_011/page (дата звернення 10.02.2021).

5. Директива 2008/50/СС Свропейського Парламенту та Ради від 21 травня 2008 року про якість атмосферного повітря та чистіше повітря для Європи. База даних «Законодавство України». URL: https://zakon.rada.gov.ua/laws/show/994_950\#Text (дата звернення 01.02.2021).

6. Директива 2004/107/СС Європейського Парламенту та Ради від 15 грудня 2004 р. про миш'як, кадмій, ртуть, нікель та поліциклічні ароматичні вуглеводні в атмосферному повітрі. (Офіційний вісник $\mathrm{CC}$, L 23, 26 січня 2005 p., с. 3-16).

7. Моніторинг якості атмосферного повітря: український та міжнародний досвід. [Аналітична записка] / Кольцов М., Шевченко Л. Київ: ГО «Фундація «Відкрите Суспільство», 2018. 13 с.

8. В яких містах України найбільш забруднене повітря. URL: https://www.ukrinform.ua/rubric-regions/3032425-v-akih-mistah-ukraininajbils-zabrudnene-povitra.html (дата звернення 10.02.2021).

9. Про затвердження гігієнічних регламентів допустимого вмісту хімічних і біологічних речовин в атмосферному повітрі населених місць: МО3 України; Наказ, Регламент від 14.01.2020 № 52. База даних «Законодавство України». URL : https://zakon.rada.gov.ua/laws/show/ z0156-20\#Text (дата звернення 10.02.2021). 